\title{
Rarity of Ceropegia bulbosa Roxb. var. lushii and protocol for its ex-situ conservation in the Indian desert
}

\author{
Suresh Kumar ${ }^{1}$, Chandan Singh Purohit ${ }^{2}$ and R. N. Kulloli ${ }^{{ }^{*}}$ \\ ${ }^{1}$ Central Arid Zone Research Institute, Jodhpur-342003 (Rajsthan), INDIA \\ ${ }^{2}$ Botanical Survey of India, AZRC, Jodhpur -342008 (Rajasthan), INDIA \\ ${ }^{*}$ Corresponding author. E-mail: r.kulloli@gmail.com \\ Received: March 13, 2016; Revised received: August 26, 2016; Accepted: November 17, 2016
}

\begin{abstract}
Over expolitation of tubers of Ceropegia bulbosa var. lushii which is a narrow endemic in the Indian Desert has drastically declined its populations and made it threatened. This was confirmed by its absence at its previously reported sites in Barmer, Jodhpur, Jalore, Jhunjhunun and Jaisalmer. Its occurance in Jhalawar, a previously reported site and at another unreported site at Jalore with density of only 4-12 plants/ha confirmed that it has become rarer. Reasons for declining populations in terms of density and occurrence of $C$. bulbosa var. lushii due to both extrinsic and intrinsic factors (= threats) have been investigated in this paper. Extrinsic factors include overexploitation of tubers, habitat loss and fragmentation due to mining. Six tubers brought from its native sites regenerated successfully at Desert Botanical Garden , CAZRI, Jodhpur. Intrinsic threats were experimentally assessed by studying its life cycle for three years. Seeds produced by these plants under captivity showed $30-35 \%$ germination. Germination, phenology and growth of plants both, from seeds for one year and tubers for three years revealed many sensitive, risk prone stages which indicated potential threat to its regeneration in its native places. These included failure to seed set due to lack of pollinator, falling of immature follicles, exposure of seeds to open sun, sapling damage by wild animals and digging out of perenating tubers by wild ungulates and human being. Both extrinsic and intrinsic factors are responsible for its rarity in the wild. It emerged that for success in its ex-situ conservation, mature seeds, availability of partial shade and safety from wild animals are essential requirements.
\end{abstract}

Keywords: Ceropegia bulbosa var. lushii, ex-situ conservation, Phenology, Population density, Rarity, Threats

\section{INTRODUCTION}

Species growing in specialized habitats within narrow geographic range and having small populations are considered as rare (Isik, 2011). If the narrow geographic range of rare and endemic species is restricted to and coincides within the national boundary, it is called 'national endemic' (Primack, 2006). One such species considered as endemic is Ceropegia bulbosa var. lushii (Nayar and Shastry, 1987, 1989). Threats faced by such endemic species increase manyfolds if these are smaller in size, sparser in density and distributed in a few isolated, disjunct, far flung areas exposed to increasing anthropogenic exploitation (Primack, 2006). Ceropegia spp. are not only botanical curiosity by way of curious fly trap flowers (Parcival, 1969) with immense diversity in flower design, corolla size, shape, coloring pattern, corona structures and mechanism for illumination of essential organs (Yadav, 1996), pollination mechanism (Chaturvedi, 1993) but are also economically important in having tubers as source of sugar, gum, fats, crude fibers and medicines. Consequently, their large scale extraction in the recent past (Kumar and Purohit, 2015) has further affected $C$. bulbosa var. lushii adversely both in terms of occurrence and density. We are not aware of any real time study on its current status in wild which is feared to be declining. Understanding reasons for its decline requires assessment of extrinsic and intrinsic risks faced by it in survival and population build up (Partel et al., 2005). Assessment of extrinsic risks is best made by comparing changes in land uses of its habitats in past with that in the present time as well as changes in species occurrences in its previously reported sites (Butchart et al., 2010; CBD, 2010). Additionally, studies on life history and phenological progression provide cue to assess intrinsic risks and threats faced by a rare species (Burgman and Walshe, 1999). We therefore, undertook studies on C. bulbosa var. lushii to i) search its occurrences in its previously reported sites, ii) locate its new populations if any in conserved areas in Rajasthan, iii) assess extrinsic risks by comparing changes in landuse and anthropogenic pressure, iv) determine intrinsic risks (= threats) by experiments on its life cycle studies, v)finalize causes of rarity of $C$. bulbosa var lushii, vi) design protocol for its ex-situ conservation in the Indian Desert

\section{MATERIALS AND METHODS}

Study area: The study was carried out in Rajasthan state of India. Average annual rainfall varied from 200 
$\mathrm{mm}$ in Jaisalmer to $550 \mathrm{~mm}$ in Sirohi. Rains are eratic, uneven and variable across the years; coefficient of variability being over $55 \%$. Extremes of temperatures like $50{ }^{\circ} \mathrm{C}$ in summer and $-2{ }^{\circ} \mathrm{C}$ in winters results in hot winds and frosts, respectively. High wind speed (20-40 $\mathrm{km} / \mathrm{hr}$ ), high evapotranspiration (1500-2000 mm/ year) (CAZRI, 2007), soils having poor soil fertility and low water retention capacity as well as deep brackish ground water pose challenge to plant survival and growth (CAZRI, 2007). C. bulbosa var. lushii occurs in rocky hilly areas in Rajasthan (Fig 1A)

Ecological sampling: Herbarium specimen in BSI, AZRC, Jodhpur (Table 1) and published floras (Pandey et al, 1983; Bhandari, 1990) of the region were examined to locate sites of its earlier reported occurrence. These were visited to confirm its occurrence and mark its location using GPS (Garmin etrex).

Collection of propagules and their regeneration ex-situ: Six tubers were collected and brought along with local soil to propagate it in the nursery of the Desert Botanical Garden (DBG) at CAZRI, Jodhpur. Growth in terms of leaf number, height, number of flower buds, fruits and seeds were recorded weekly for the first three month and biweekly for next three months till the end of growing period. Phenological events were also recorded simultaneously (Fig 1A-I). Freshly collected seeds were shade dried.

Experimental site details: Ex-situ conservation was carried out at the Botanical Garden of Central Arid Zone Research Institute $\left(26^{\circ} 18^{\prime} \mathrm{N}\right.$ and $\left.73^{\circ} 01^{\prime} \mathrm{E}\right)$ from 2009-2011.

Germination: Its seeds were collected from two sources (1) Plants regenerated from the tubers maintained at Desert Botanical Garden, CAZRI (DBG) and (2) from plants with bulbs growing in nature at Sundha Mata hill and Jagannath goshala, Jalore in the year 2009-2011 brought to Desert Botanical Garden, CAZRI and Jodhpur and grown there. Fifty seeds were sown in petriplates lined with Whatman filter paper (Fig1F and G) in three replicates in the month of June in three different conditions (i) room temperature in diffused room light (ii) room temperature in dark condition and (iii) open sun light condition at ambient temperature. Simultaneously, seeds were sown in polythene bags $($ Fig1H) with soil and FYM mixture in green house nursery. Watering was done daily and germination was recorded up to $28^{\text {th }}$ day as per ISTA rule, 1996. Czabatores index (1962) was used to calculate various values according to following equations.

$$
\text { Germination value }(\mathbf{G V})=\text { Final MDG } \times \text { PV. of MDG }
$$

Where MDG is the mean daily germination and PV is peak value of MDG which is the highest value obtained by dividing the percentage germination by the number of days from the experiment.

Mean Germination Percent $(\mathbf{G} \%)=\frac{\text { Total no. of seeds germinated }}{\text { total no. of seeds in all replicates }} X 100$

$$
\begin{aligned}
& \text { Mean daily germination }(\mathrm{MDG})=\frac{\text { Cumulating total as } \% \text { of total seeds }}{\text { No. of days after start of experiments }} \\
& \text { Germination Energy }(\mathrm{GE})=\frac{1 / 4 \text { of maximum no. of seeds germination in a day }}{\text { total no. of seeds in all replicates }} \mathrm{X} 100 \\
& \text { Germination period }(\mathrm{GPD})==\text { days with the maximum no. of seeds germinated }
\end{aligned}
$$

On emergence of plumule, seedlings were exposed to sunlight and transferred in pots with FYM and soil mixture $(1: 2)$ and treated with fungicide (Bavistin) and termiticide (Foret).

Transplantation: Since its roots are very delicate, transplanting in soil required utmost care. Its seedlings were watered daily, avoiding water logging. Young seedlings were protected by wire mesh cages so that they could grow better and stronger. These were regularly irrigated on alternate day to see their survival and growth. Observations were recorded on height, collar diameter and number of leaves at weekly interval in the first three months after germination and at fortnightly interval thereafter. These experiments were repeated in the year 2010 and 2011. Based on field data and its regeneration under controlled conditions, a number of weaker stages in its life cycle were identified as per Mckinney (1997) and Pilgrim et al. (2004) as threat to its survival and become basis to finalize protocol for its conservation.

\section{RESULTS AND DISCUSSION}

Morphology: Locally known as Kharpude, C. bulbosa var. lushii is endemic to India and is considered threatened species (Pandey et al., 1983). Morphometric analysis of its plants raised from tubers/seeds observed for three years revealed that it is a perennial, climbing herb having a spherical oblong, root-tuber $(2.5-4 \mathrm{~cm})$. It has glabrous slender stem that dries off during December to May and sprouts with onset of rains. Leaves are elliptic or elliptic-lanceolate $5-10 \mathrm{~cm}$ long and $1-1.5 \mathrm{~cm}$ wide (Fig1B and C). Pedunculate, umbellate cyme has flowers with peduncles $2-3 \mathrm{~cm}$ long. (See detailed taxonomic treatment in Bhandari, 1990). Flowering and fruiting were seen in July to November. C. bulbosa var. lushii distinctly differs from C. bulbosa var. bulbosa. The var. lushii has elliptic or elliptic-lanceolate leaves while var. bulbosa has oblong or obovate leaves. Medicinally, paste of seeds is dropped in the ear to cure deafness. Decoction of tuber is taken orally to get rid of urinary bladder stone. The tuber is eaten either raw or cooked.

Ecological distribution: Appraisals of vegetation in the past four decades in the Rajasthan (Pandey and Padhye, 2007; Shankar and Kumar, 1987, 1988; Kumar and Shankar, 1985, 1987; Kumar, 1996, 1997, 1998, 2002, 2003a, 2003b; Kumar et al., 2002; Shetty and Singh, 1993) reported it from a very few locations because it is hidden under gregarious shrubs of $E u$ phorbia caducifolia, Grewia tenax, Rhus mysorensis 
Suresh Kumar et al. / J. Appl. \& Nat. Sci. 8 (4): 2155-2163 (2016)

Table 1. Previous and present status of Ceropegia bulbosa var. lushii in Rajasthan.

\begin{tabular}{lll}
\hline \multicolumn{2}{c}{ Location of occurrence reported in previous works } & Location of occurrence being reported in present work \\
\hline Site & Authors & Current status in survey in 2009-2011 \\
\hline Barmer & Bhandari 1990 & Not present \\
Mandore, Jodhpur & Bhandari 1990, Shetty \& & Not present \\
& Singh, 1991 & \\
Kankaria, Jalore & Shetty \& Singh, 1991 & Not present \\
Ramgarh, Jaisalmer & Shetty \& Singh, 1991 & Not present \\
Mandri-Jhunjhunu & Shetty \& Singh, 1991 (BSJO- & Not present \\
& 17727, 17728) & \\
Jhalawar & Shetty \& Singh, 1991 & Ralawata (Khanpur) \\
& - & Chuna Bhati-1 (Jhalawar district*); Sundha Mata hills site-1 \& \\
& & 2 and Jagannath goshala (Jalore district)* \\
\hline
\end{tabular}

*Newly reported sites during our survey.

Table 2. Relation between number of flowers and fruits of six plants. set in different years.

\begin{tabular}{ccccccc}
\hline \multirow{2}{*}{ Year } & \multicolumn{3}{c}{ Plant raised from tubers (n=6) } & \multicolumn{3}{c}{ Plant raised from seeds (n=6) } \\
\cline { 2 - 7 } & $\begin{array}{c}\text { No. of } \\
\text { flowers }\end{array}$ & $\begin{array}{c}\text { No. of } \\
\text { fruits }\end{array}$ & $\begin{array}{c}\text { Percent of flower maturing to } \\
\text { fruit }\end{array}$ & $\begin{array}{c}\text { No. of } \\
\text { flowers }\end{array}$ & $\begin{array}{c}\text { No. of } \\
\text { fruits }\end{array}$ & $\begin{array}{c}\text { Percent of flower maturing to } \\
\text { fruit }\end{array}$ \\
\hline 2009 & 45 & 12 & $26.67 \%$ & - & - & - \\
2010 & 75 & 23 & $30.67 \%$ & - & - & - \\
2011 & 78 & 17 & $21.79 \%$ & 69 & 11 & $15.94 \%$ \\
\hline
\end{tabular}

and Dichrostachys cinerea. Researchers are therefore, unanimous about its patchy, isolated and restricted occurrence (Bhandari,1990; Gaikwad et al., 1989; Patil, 1990; Supate et al., 1990 and Yadav, 1996). Its recent status of distribution and abundance is not known. We searched it in all the earlier reported places of its occurrence i.e., at Jhunjhunu (Mandri), Khanpur (Jhalawar), Kankaria (Jalore), Ramgarh (Jaisalmer) and Jodhpur (Mandore) but failed to record from all except one site at Khanpur (Jhalawar). Instead some new areas of its occurrence have been seen such as at sacred groves, i.e. forest area left around a temple of Sundha Mata and Jagannath Goshala (Jalore) and Chunabhati (Jhalawar) where its presence was in patches at higher elevation (Table-1). It emerged that C. bulbosa var. lushii had a very restricted occurrence in the protected area around Sundha mata temple and Jagannath Goshala in Jalore and conserved forest area of Khanpur and Chunabhati in Jhalawar district. Even at this site, it was localized at an elevation of $346.5 \mathrm{~m}$ to $563.5 \mathrm{~m}$ in an area of 0.1 ha having a population of 412 plants only confirming its rarity. These results confirm to "double jeopardy" characteristic defined by Lawton (1993) in respect of rare species which has not only narrow distribution but also low abundance.

Environmental characteristics of experimental site : Soils of Desert Botanical Garden $\left(26^{0} 18^{\prime} \mathrm{N}\right.$ and $73^{0} 01$ E ) had $\mathrm{pH} 8.1$, organic carbon $0.22 \%$, nitrogen $0.03 \%$, available phosphorus $16 \mathrm{~kg} / \mathrm{ha}$, available potassium $225 \mathrm{~kg} / \mathrm{ha}$. The soil had $85 \%$ sand, $8.1 \%$ silt and $5.5 \%$ clay and thus classified as coarse loamy, mixed hyperthermic, camborthids according to USDA classification. Total rainfall during three years was $212 \mathrm{~mm}$, $562.2 \mathrm{~mm}$ and $319.7 \mathrm{~mm}$ in the years 2009, 2010 and 2011, respectively. Total rainy days were 22, 42 and
36 during respective years. Climate of the site was observed to be arid.

Regeneration through tubers: Tubers of this variety brought from Jalore were raised in 2009 in controlled conditions of wire house. It gained good height (over 2 $\mathrm{m}$ ) in year 2010 as compared to that in the year 2011 and 2009 (Fig. 3). Numbers of leaf pairs (60) were however, more in year 2010 as compared to 2011 and 2009 and also throughout the growing period till their fall by the end of December.

Number of buds was maximum (16) in year 2011 as compared to 2010 and 2009 where as number of flowers was maximum in the second and third week of October, 09 as compared to 2010 and 2011 (Fig 4 and 5). After December, 2009 the bulbs became dormant and were kept as such without watering in the same pots. There was sudden flower fall without formation of follicles and consequently no seeds could be collected in 2009 for its regeneration in the next season. Their bulbs were maintained as the source of regenerating propagules for future. In the year 2010, the tubers showed re-growth from 7 May and continued to attain $2 \mathrm{~m}$ height by September end. Thereafter there was no growth (Fig 2). Longer growing period due to better rainfall in 2010 resulted in its increased height. For same reasons, number of leaves produced by each plant was also more in 2010 (Fig 3). Fruits were not formed in 2009. In 2010, fruits formed were maximum as compared to 2011 (Fig. 6).

Phenology of $C$. bulbosa var. lushii raised from tubers: The most important events are leaf initiation and flowering. Leaf initiation occurred on $12^{\text {th }}$ day $\left(\mathrm{SD}= \pm 6.64\right.$ days) in 2010 and on $10^{\text {th }}$ day $(\mathrm{SD}= \pm 5.11$ days) in 2011 after sprouting of bulb and reaching its peak in month of September (Fig 7). Flower appeared 

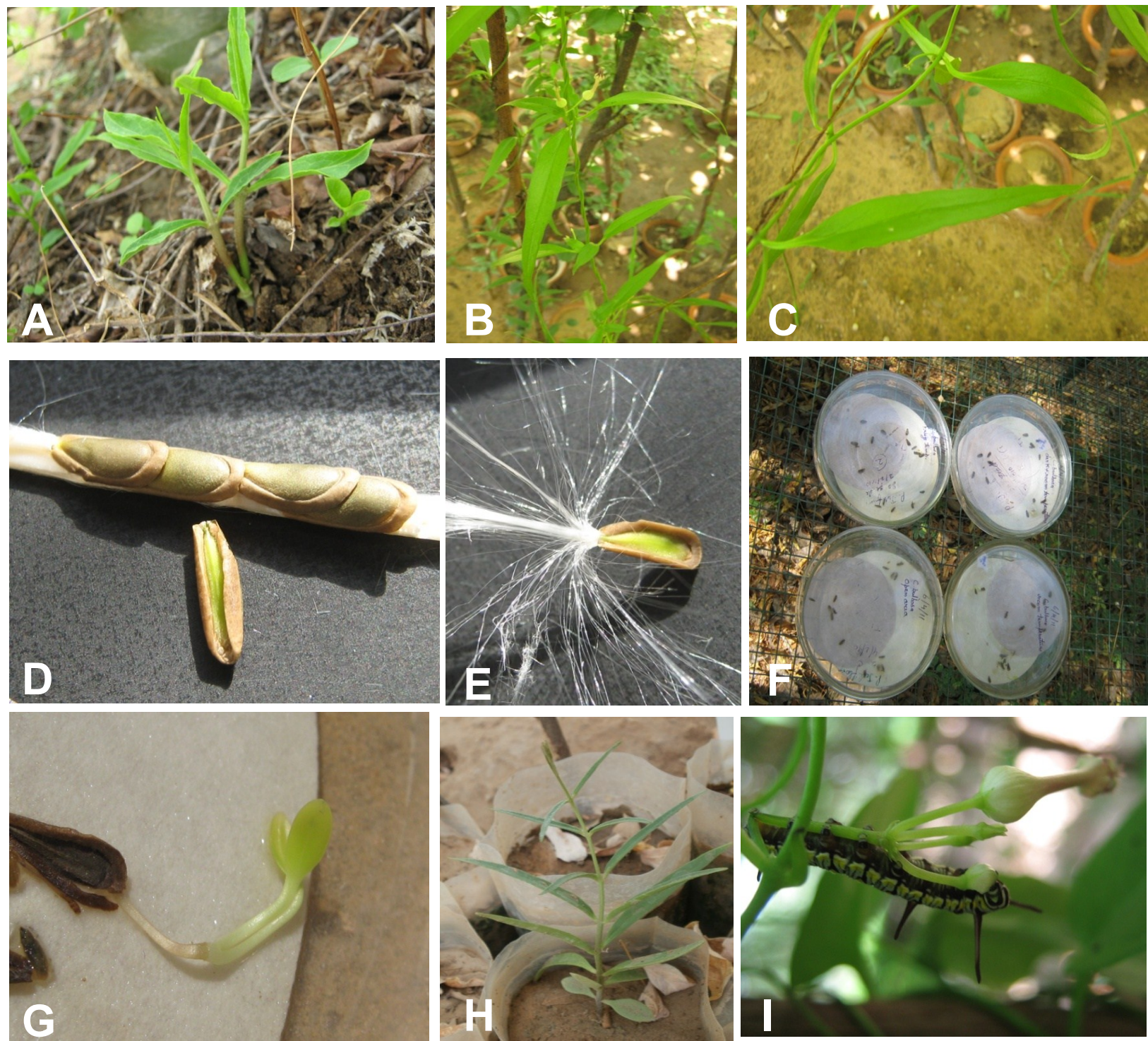

Fig.1. Ceropegia bulbosa var. lushii: A-Natural plant; B-Plant with flowering; C-Close up of leaves; D-Seeds in follicle; E- close up of seeds with fur; F-Seed germination in different treatment in Petri plate; G-germinated seeds in Petri plate; H-Seed germination in polythene bag; I-Caterpillar on flower germination.

on $90^{\text {th }}$ day $\left(\mathrm{SD}= \pm 19.08\right.$ days) in 2010 and on $74^{\text {th }}$ day ( $\mathrm{SD}= \pm 15.06$ days) in 2011 (Fig 8) after sprouting of bulbs. Availability of seeds from fruits in the end of growing season i.e. winter ensures availability of seeds for dispersal during December to May-June to become available during rainy season to germinate.

Regeneration through seeds: Germination studies revealed that seeds both from the wild as well as DBG did not germinate in open sunlight condition. Maximum germination value was in seeds of wild source placed in dark (Fig. 9). Germination value was nearly half $(0.08$ to 0.06$)$ in seeds kept in room temperature in diffused room light conditions, in respect of seeds from both wild and Desert Botanical garden. Seeds from DBG kept in dark in room temperature had minimum germination value. Similar trend was noted in respect of mean germination percent (Fig. 10). Germination period (number of days with maximum number of seeds germination) was shortest in DBG seeds kept in room temperature diffused light (3 days) while it was longer ( 7 days) in wild seeds in both dark as well as diffused light in room temperature and longest (9 days) in DBG seeds kept in dark in room temperature. Evidently, germination requirements of seeds brought from two different environments varied. Wild seeds took longer period to accomplish maximum germination value, maximum mean germination percent and germination energy in darkness in room temperature (Fig. 11). Though germination period (Fig. 12) was different in seeds in diffused light at room temperature, their mean gernimation percentage and value were comparable. These results showed that for mass scale 

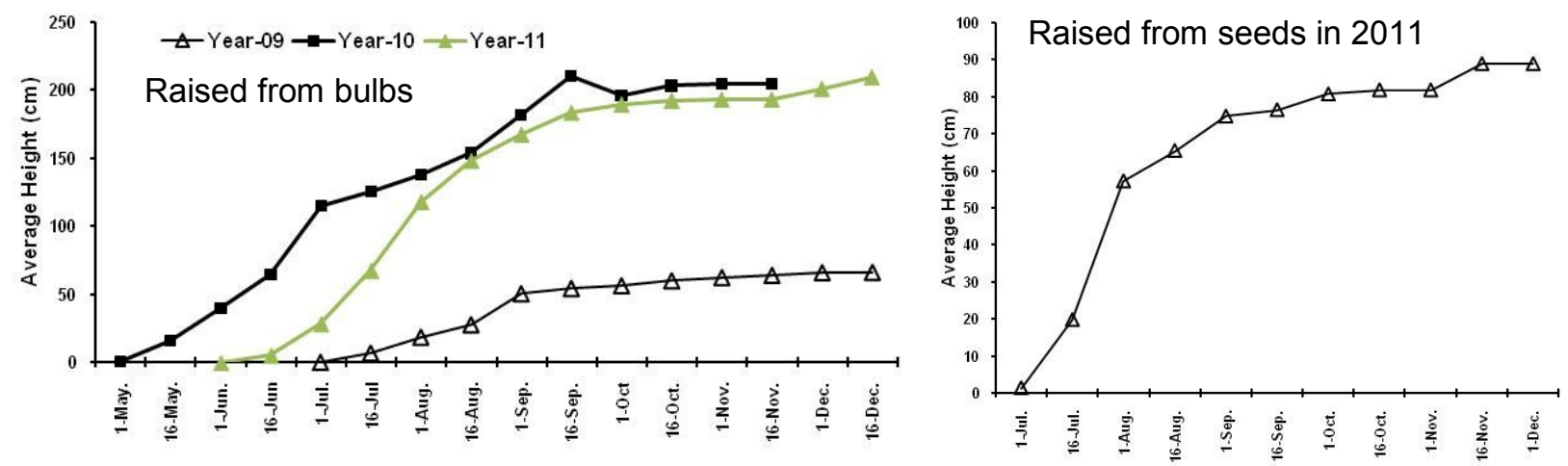

Fig. 2. Average height of C. b. var. lushii plants.
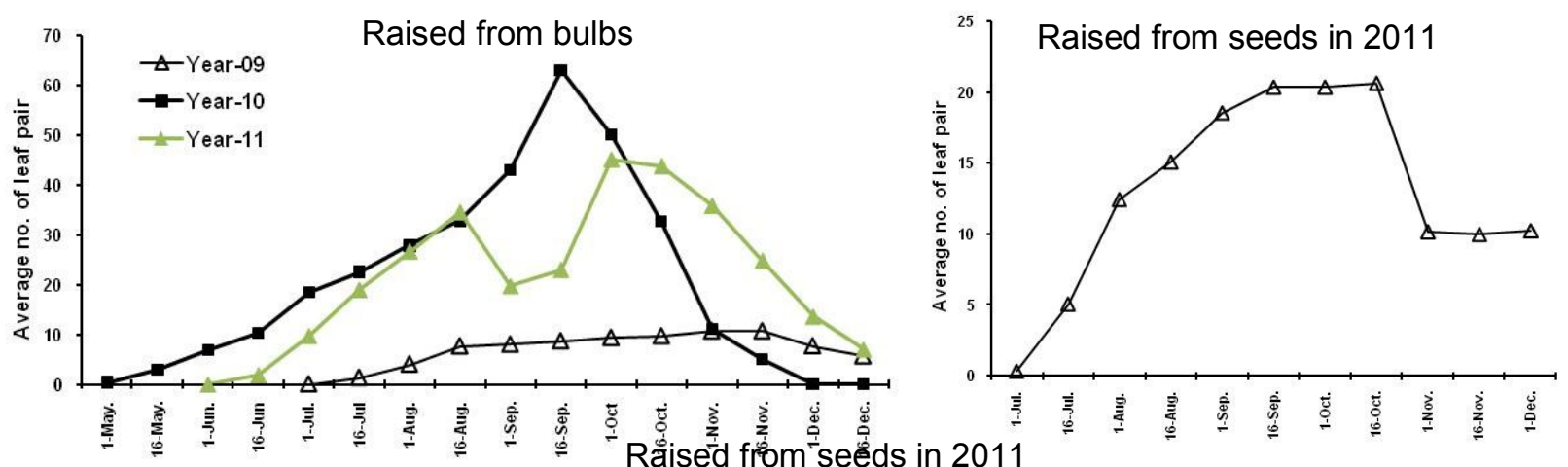

Fig. 3. Average number of leaf pairs.
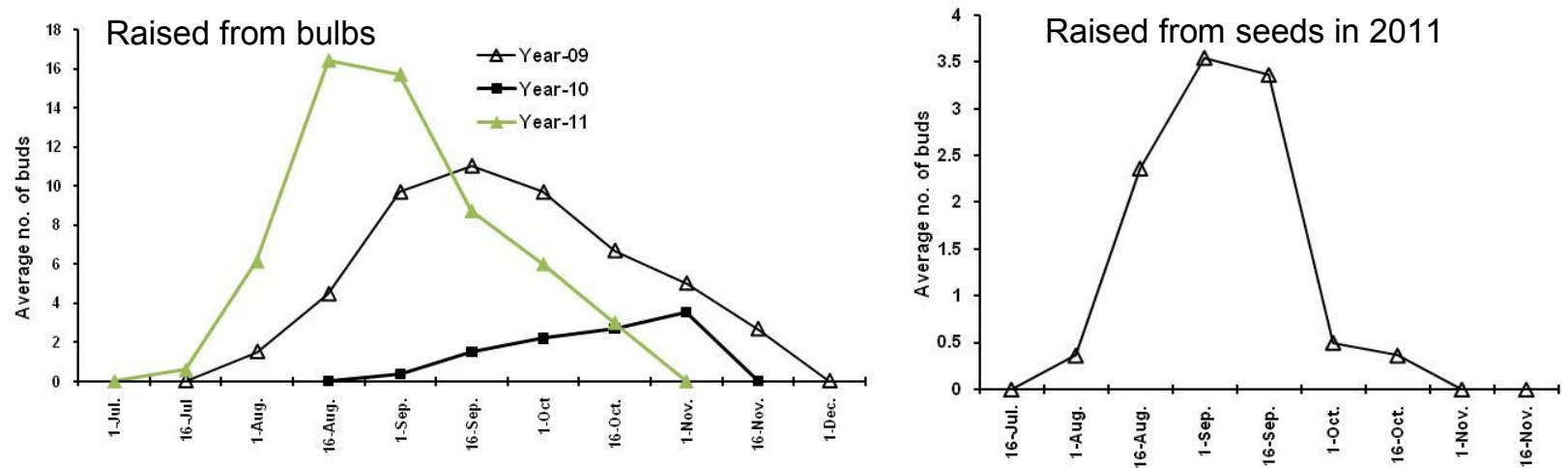

Fig. 4. Average number of buds.

multiplication of this species, it could be regenerated through seeds kept at room temperature in dark (if wild seeds) and in diffused light (if domesticated plants seeds), though success varies from 35 to $50 \%$ only. It therefore needs to be investigated to find out its germination requirements more exectly so as to ensure germination success.

The percentage germination was high in room temperature $(35 \%)$ and lowest in open sun light condition (5\%). Though germination was comparable in diffused light and dark, it was favoured in darkness in respect of all parameters of germination studied. Similar behaviour has been reported in many other species like
Helichysum stoechas, Helianthemum hirtum, Helianthemum apennium (Martin et al., 1995); Polygonum species (Nashitani and Masuzawa 1996; Petrocoptis grandi flora (Navarro and Guitian, 2003). Better germination in dark is an adaptive strategy to increase germination percentage for seeds that fall into crevices and cracks, as also reported in Petrocoptis in Iberian Peninsula (Navarro and Guitian, 2003). Furs in its seed enable its transport by wind to longer distance which has both positive and negative impacts. Positive impacts include possibility to reach more number of favorable sites. Negative would include being trapped in the canopy and spines of all other plants. Negative 

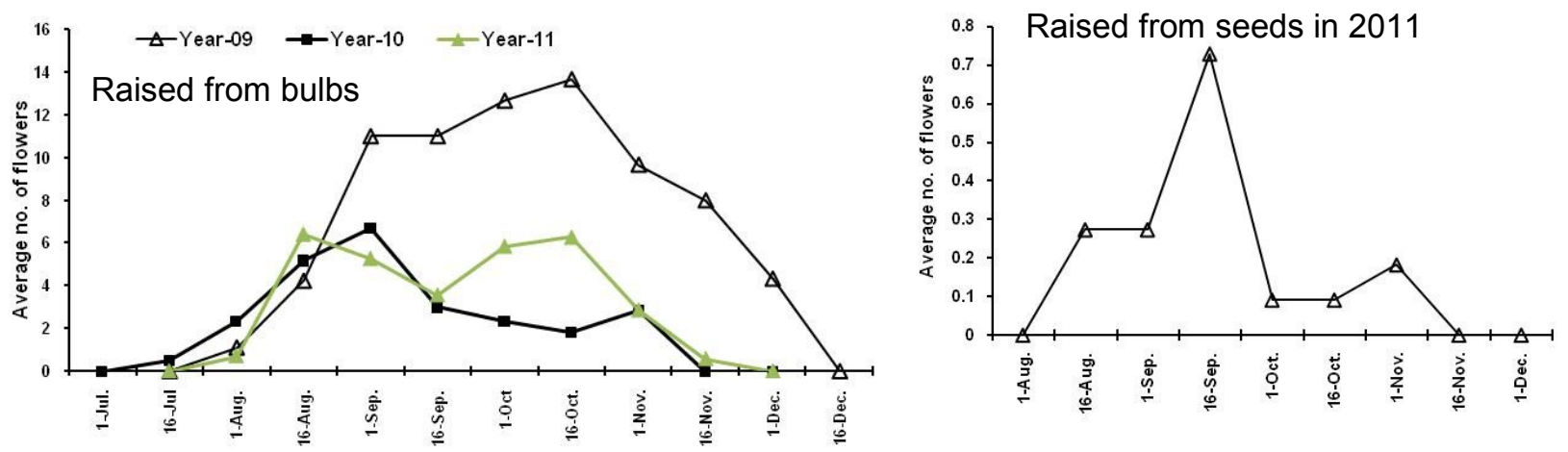

Fig. 5. Average number of flowers.
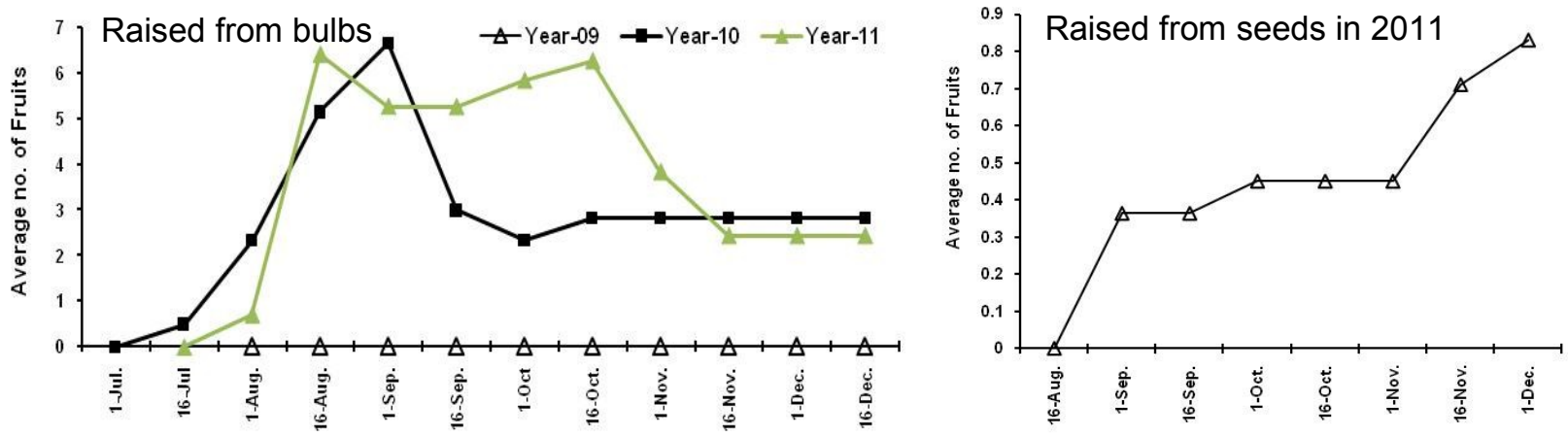

Fig. 6. Average number of fruits.

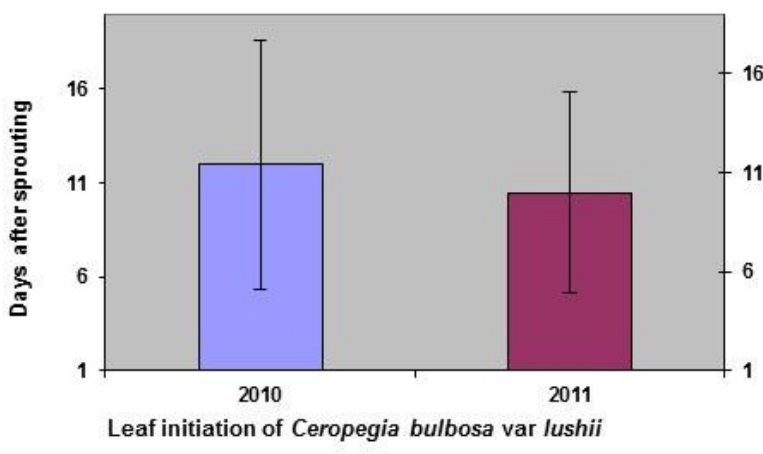

Fig. 7. Leaf initiation of C. bulbosa var. lushii raised from bulbs.

impacts are likely to far outweigh the positive once as we have not seen any of their seedlings around mother plants or even at a distance from it.

Raising plant from seeds and from bulbs has obvious differences. Height, number of leaves and number of buds are nearly three times more in the plants raised from tubers than seeds (Fig. 4, 5 and 6). Likewise average number of flowers and fruits ware also 12 and 6 times more in plants raised from bulbs than from seeds. Obviously, stored food in tuber provided much needed nutrients enhancing both vegetative as also reproductive growth. This also partly explained that newer saplings in nature do not make so many flowers

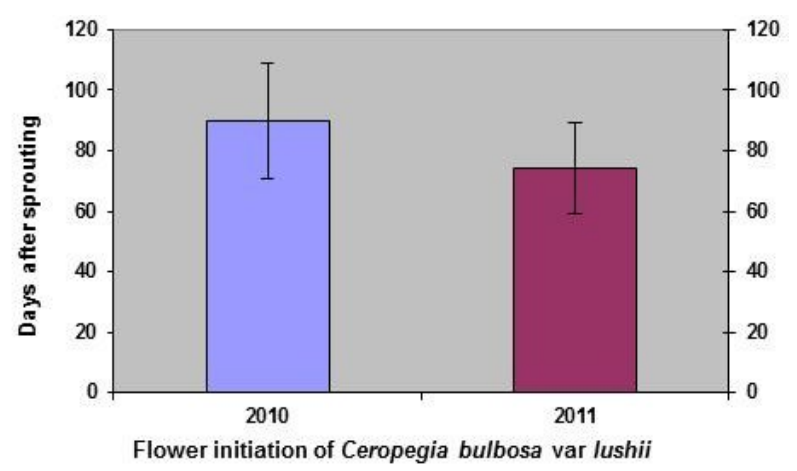

Fig. 8. Flower initiation of C. bulbosa var. lushii raised from bulbs

to develop into fruits. In fact fruit to flowers percentage was also nearly $25-30 \%$ in plants raised from bulbs and $15.94 \%$ in plants rose from seeds.

Phenology of plants raised through seeds: Vegetative growth and flowering are two important phenophases that help at the end to build up seed and seed bank. Vegetative growth in arid plants is conditioned more by the availability of water in root zone than any other factor. Since these plants were kept optimally irrigated, role of water in modulating growth is ruled out. The variation in temperature, day length and humidity during May to December would require plants to have more flexibility in vegetative growth so that 


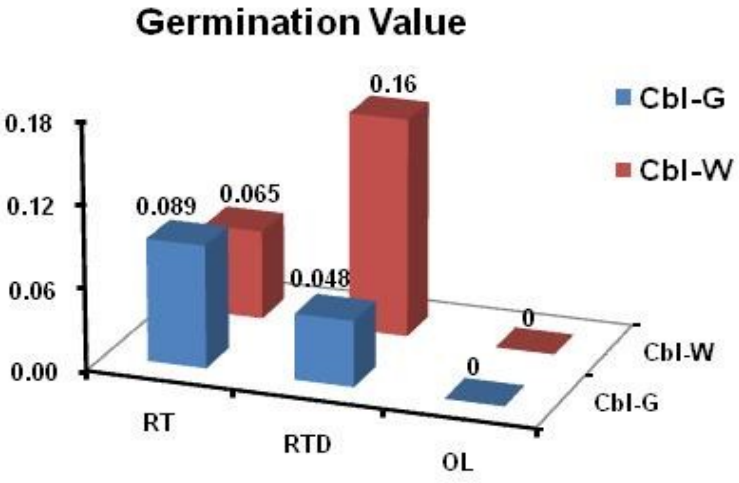

Fig. 9. Germination value in seeds sourced from wild $(W)$ and Desert Botanical Garden $(G)$.

\section{Germination Energy Graph}

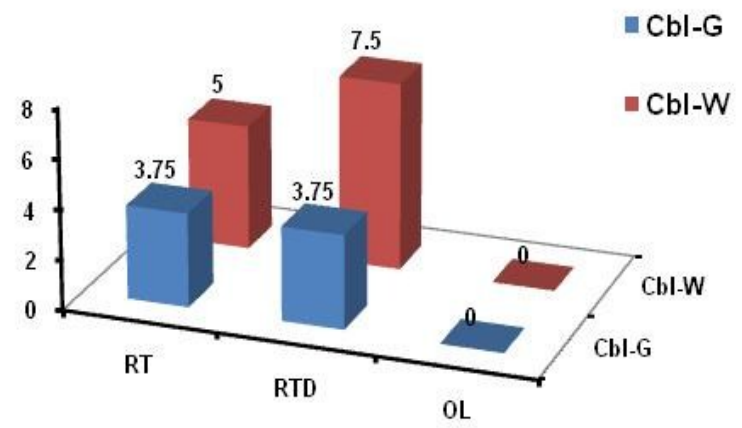

Fig. 11. Germination energy in seeds sourced from wild (W) and Desert Botanical Garden $(G)$.

enough raw material become available for making more and more seeds during reproductive phase. Going by this corollary, flowering and fruiting should show more synchrony compared to vegetative phase. This is evidently the case in respect of vegetative growth in both years; more asynchrony in leaf initiation and better synchrony in flower initiations (Fig.8). Similar findings have also been reported by Milla et al. (2010) in respect of 11 species (Arbutus unedo L., Quercus ilex L., Quercus faginea Lam., Quercus coccifera L., Buxus sempervirens L., Pistacia lentiscus L., Pistacia terebinthus L., Bupleurum fruticosum L., Lonicera implexa Aiton, Amelanchier ovalis Medik. and Cistus laurifolius L.) in Spain. Further, leaf appearance along growing twine continued up to November in 2009, September in 2010 and bimodal growth in 2011. Flower bud initiation, flowering and fruiting also closely followed leaf growth, most often overlapped after 1.5 to 2 months of vegetative growth. Milla et al. (2010) described phenophasic overlapped species (Quercus ilex L., Arbutus unedo L., Cistus laurifolius L.) as those which display "high synchrony, fulfill phenological cycle in a short period and are recent phylogenetic origin." While phenophase overlap may imply resource driven competition among

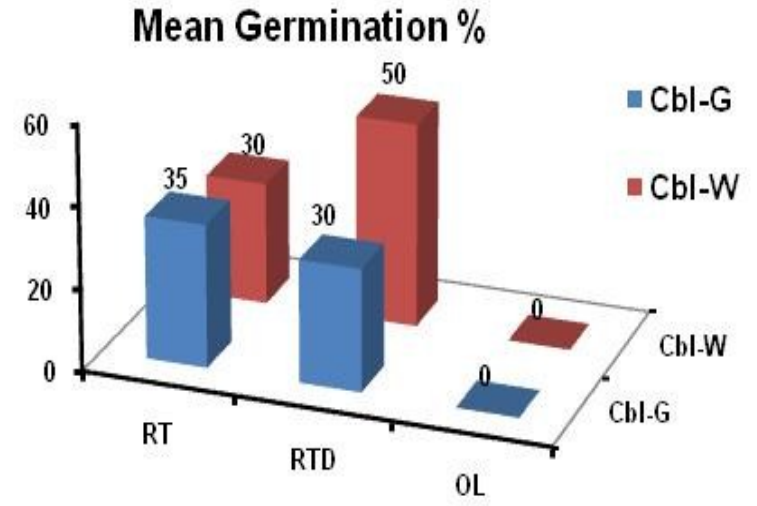

Fig. 10. Mean germination percentage in seeds sourced from wild $(W)$ and Desert Botanical Garden $(G)$.

\section{Germination Period days}

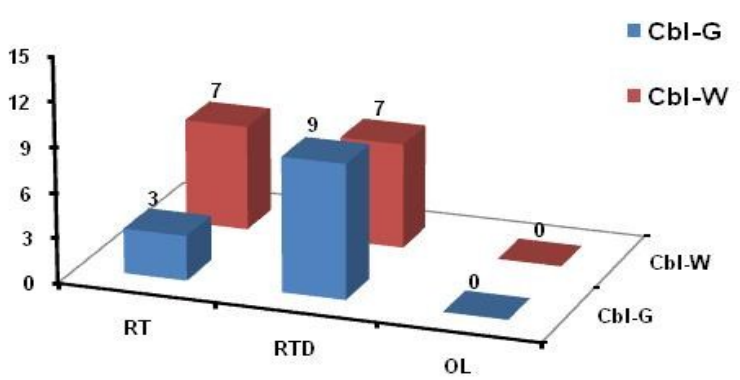

Fig. 12. Germination period (days) in seeds sourced from wild $(W)$ and Desert Botanical Garden $(G)$.

overlapping phenophase (Castro Diez and MontserratMarti, 1998: Chapin et al., 1990: Hoffmann and Alliende, 1984), it does impart an adaptive edge for survival and continuance of its progeny in arid climate where rains (= moisture) are so uncertain that plants are in hurry to produce whatever little seeds they can and as early as possible. If there is a second good spell of moisture availability, they can have another flush of flower and this explains bimodality in Figs. 3, 5and 6. Viewed in this context, overlap in phenophase in desertic plants is not merely a resource driven competition but also a perfect mechanism of resource partitioning and sharing by default, to ensure continuance of progeny. That is why peak number of fruits is attained by 1-15 September even if rains came in 2009, later than September which only added more leaf pairs and a few flowers but no fruits (Fig 4-6).

Causes of rarity: Observation at the site of its occurrence and during regeneration led to identify following threats to its survival and causes of rarity such that it is restricted in distribution and seems to have specific edaphic/climatic requirements. 
Extrinsic factors: 1.) It occurs in hilly areas, many of which are being mined for a variety of minerals in Rajasthan (Kumar and Kumar, 2014). Area under mining has also substantially increased from $0.13 \%$ in 2002 to $0.15 \%$ in 2013 (Moharana, 2015). All these have culminated in modification and destruction of the habitats resulting in further decline and fragmentation of populations. Habitat loss and degradation have also been identified as leading causes of species rarity and extinction in USA also (Wilcove et al., 2000), Mexico (Ceballos and Navarro, 1991), China (Li and Wilcove, 2005) and Canada (Venter et al., 2006).

2.) Local people informed that it used to be easily available in wild in past, but now not seen in forests. They also confirmed that its tubers are eaten by cowboys, cattlemen and even wild animals as observed in the field. Such overexploitation being cause of rarity has been recognized even at global level for $7.6 \%$ of IUCN red listed species (Gurevitch and Padilla, 2004).

3.) Sudden temperature fluctuations also kill them as 18 saplings planted in the field of DBG did not survive in July - August, 2011.

4.) Most of the seeds are lost along slopes and as such do not reach proper niche for germination and seedling establishment.

Intrinsic factors: 1.) It has some of the most complicated flowers with highly specialized pollination mechanisms and absence of species-specific pollinators result in low fruit and seed setting (we recorded no seed set in the year 2009). Pilgrims et al. (2004) also reported absence of pollinator as major cause of rarity in flora of UK.

2.) Perennation of the tubers during rest of the year is essentially fraught with risk to its survival in nature (Two tubers out of seven died even in Net house conditions).

3.) Its tubers are highly susceptible to microbial decay as observed in our net house.

4.) Its aerial plant parts are also attacked and eaten by caterpillars (Fig. 1I).

5.) Germination percent is also low (35\% in our experiments).

6.) Longer duration of 3-7 days between imbibition and germination as found in this study is often fraught with risks of situations like non availability of moisture. Thus even if many seeds germinate; these will die in the lack of moisture and would not add to its populations.

\section{Conclusion}

This is the first report of C. bulbosa var. lushii to validate the status of earlier populations in present scenario. Its absence in five earlier reported sites and occurrence at only two sites now confirms rarity of this narrow endemic species. This is also a first study on experimentally determining the causes of rarity of any RET \& E species on the basis of empirical data on its life cycle events studied for three years. Both extrinsic and intrinsic causes of rarity have been found to over- lap in case of C. bulbosa var. lushii. It also emerged that following five key requirements need to be met for success in its ex-situ conservation i) In the beginning of summer its follicles split scattering the seeds on surface which flew in the air by comma. So seeds need to be collected from intact follicle before split; ii) Seeds removed from the follicle need to be shade dried and stored in cotton bags in dry cool places; iii) Seeds need to be germinated in poly begs/pots with soil + FYM mixture in shade condition. It ensures 35\% germination; iv) Young seedlings should be protected by wire mesh cages to protect from damage by wild animals. Watering is provided at one day interval; v) After leaf fall in winter, hibernating tubers should be preserved in-situ for sprouting in next season.

\section{ACKNOWLEDGEMENTS}

We express our gratitude to Director, Central Arid Zone Research Institute, Jodhpur for providing facilities and encouragements. We thank Ministry of Environment and Forests, Govt. of India, New Delhi for financial support for this study (F. No. 10/34/08-CS/ BG/55 dt. 17.10.2008)

\section{REFERENCES}

Bhandari, M.M. (1990). Flora of the Indian Desert. Scientific Publishers, Jodhpur (Revised Edition).

Burgman, M.A., Keith, D.A. and Walshe, T.V. (1999). Uncertainly in comparative risk analysis for threatened Australian plant species. Risk Analysis, 19:585- 598 doi: 10. 1111/J. 1539-6924.1999. tb 00430.X

Butchart, S.H.M., Walpole, M., Collen, B., Van Strien, A., Scharlemann, J.P.W, and Almond, R.E.A. (2010). Global biodiversity: indicators of recent declines. Science, 328, 1164-1168

Castro-Diez, P. and Montserrat-Marti, G. (1998). Phenological pattern of fifteen mediterranean phanerophytes from Quercus Ilex communities of NE- Spain. Plant Ecology, 139:103-112

CBD (2010). Global biodiversity outlook3. Montreal: Secretariat of the Convention on Biological Diversity.

Ceballos, G., and Navarro, D. (1991). Diversity and conservation of Mexican mammals. Pp.167-98 in Latin American mammalogy: History, biodiversity, and conservation, ed. M. A. Mares and D. J. Schmidly. Norman: University of Oklahoma Press.

Chapin, F.S., Sculeze, E.D., Mooney, H.A., (1990). The ecology and economics of storage in plants. Annual Review of Ecology and Systematics, 21:423-447

Chaturvedi, S.K. (1993). Significance of light windows in the pollination of some Indian Ceropegias (Asclepiadaceae), Cactus and Succulent Journal (U.S.), 65:148-151

Gaikwad, D.K., Supate, A.R., Yadav, S.R. and Chavan, P.D. (1989). Occurrence of crassulacean acid metabolism in stem tissues of Ceropegia juncea Roxb. Photosynthetica, 23:216-220

Gurevitch, J. and Padilla D.K. (2004). Are invasive species a major cause of extinctions? Trends in Ecology and Evolution, 19, 470-474 
Hoffman, A. and Alliende, M.C. (1984). Interactions in the patterns of vegetative growth and reproduction in woody dioecious plants. Oecologia, 61:109-114

Işik, K. (2011). Rare and endemic species: why are they prone to extinction? Turkish Journal of Botany, 35:411-417

Kumar, S. (1996). Trends in structural compositional attributes of dune interdune vegetation and their edaphic relations in the Indian Desert. Vegetatio, 124 : 73-93

Kumar, S. (1997). Vegetation of the Indian arid ecosystem. pp: 71-79 In. Surendra Singh and Amal Kar (eds). Desertification control in the arid ecosystem of India for Sustainable Development. Agro-Botanical Publishers (India) $393 \mathrm{pp}$

Kumar, S. (1998). Vegetation resources in the indian arid zone pp: 89-119 In Fifty years of Arid Zone Research in India (Eds. Faroda AS and Singh M.) CAZRI, Jodhpur, 478pp.

Kumar, S. (2002). Regional biodiversity profiles: arid and semi Arid areas. Pp. 292-306. In. Singh, J.S. (ed.) National Biodiversity Strategy and Action Plant National Terrestrial Ecosystem, BHU VARANASI $422 \mathrm{pp}$.

Kumar, S. (2003a). Vegetation Resources pp. 47-55. In M.A.Khan, P.C. Moharana and S.K. Singh (Eds.). Integrated Natural Resources and Environmental Impact Assessment for Sustainable Development of Ganganagar District, Rajasthan. Central Arid Zone Research Institute, Jodhpur.

Kumar, S. (2003b). Vegetation Resources pp.70-78. In M.A. Khan and Balak Ram (Eds.). Integrated Natural Resources and Environmental Impact Assessment for Sustainable Development of Hanumangarh District, Rajasthan. Central Arid Zone Research Institute, Jodhpur.

Kumar, S. and Shankar, V. (1985). Vegetation ecology of the Guhiya catchment of the Upper Luni Basin. Tropical Ecology 26: 1-11

Kumar, S. and Shankar, V. (1987) Vegetation ecology of Bandi catchment in the Upper Luni Basin Western Rajasthan. Tropical Ecoogy, 28:246-258

Kumar, S. and Kumar, P. (2014). Rehabilitation of lignite mine spoils in the indian arid zone-An Ecological Approach. Annals of Arid Zone, 53 (3\&4): 121-136

Kumar, S., Jadhav, R., Thakkar P.S. and Sastry, K.L.N. ( 2002). Grassland Mapping in Gujarat using remote sensing and GIS Techniques: Jamnagar district. SAC \& CAZRI $36 \mathrm{p}$.

Kumar, S. and Purohit, C.S. (2015). Conservation of Threatened Desert Plants. Scientific Publishers. 148 pp.

Lawton, J.H. (1993). Range, population abundance and conservation. Trends in Ecology and Evolution, 8:409-12

Li, Y.M., and Wilcove, D.S. (2005). Threats to vertebrate species in China and the United States. Bio-Science, 55:147-53

Moharana P.C. (2015). Desertification status mapping of Rajasthan monitoring SAC project report (unpublished)

Martain, A., Grzeskowiak, V. and Puech, S. (1995). Germination variability in three species in disturbed Mediterranean environments. Acta Oecologia, 16:479-490
Mc KinneYt, M.L. (1997). Extinction vulnerability and slectivity: Combining ecological and paleontological views. Annual Review of Ecology and Systematics, 28:495-516

Milla, R., Castro-Die, P. and Montserrat-Marti, G. (2010). Phenology of mediterranean woody plant from N E Spain : Sychrony, seasonality and Relationship among phonophases. Flora, 205:190- 199

Navarro, L. and Guitian, J. (2003). Seed germination and seedling survival of two threatened endemic species of northwest Iberian peninsula. Biological Conversation, 109:313-320

Nayar, M.P. and Shastry, A.R.K., (eds.) (1987-1989). Red Data Book of India Plants. Vol. I-III. BSI. Calcutta.

Pandey, R.P. and Padhye, P.M. (2007). Studies on phytodiversity of arid Machia Safari Park-Kailana in Jodhpur (Rajasthan). Bulletin of Botanical Survey of India, 49(14): $15-78$

Pandey, R.P., Shetty, B.V. and Malhotra, S.K. (1983). A preliminary census of rare and threatened plants of Rajasthan. In Jain SK and Rao RR (eds.), An Assessment of Threatened Plants of India pp. 52-62. BSI, Howrah

Parcival, M.G. (1969). Floral Biology (Pergaman Press) Oxford 1-243

Partel, M., Kalamees, R., Reier, D., Tuvi, E.L., Roosaluste, E., Vellak, A. and Zobel, M. (2005). Grouping and prioritization of vascular plant species for conservation: Combining natural rarity and management need. Biological Conservation, 123:271-78

Patil, V.N. (1990). Morphotaxonomical studies in Asclepiadaceae: Genus Ceropegia Linn. And Brachystelma R. Br. M. Phil. Dissertation, Shivaji University, Kolhapur.

Pilgrim, E.S., Crawley, M.J., and Dolphin, K. (2004). Patterns of rarity in the native British flora. Biological Conservation, 120:161-70

Primack, R.B. (2006). Essentials of Conservation Biology. Sinauer Assoc., Inc., Sunderland, MA.

Shankar, V. and Kumar, S. (1987). Grazing Resources of Jaisalmer : Ecology and development planning with special reference to Sewan Grazing lands. CAZRI Monograph No. 28 pp: 91 CAZRI Jodhpur

Shankar, V. and Kumar, S. (1988). Vegetation ecology of the Indian Thar Desert International Journal of Ecology and Environmental Science, 14: 131-155

Shetty, B.V. and Singh, V. (1993). Flora of Rajasthan VolI,II,II. Botanical Survey of India

Supate, A.R., Gaikwad, D.K., Yadav, S.R. and Chavan, P.D. (1990). Crassulacean Acid Metabolism feature occur in leafy forms of Ceropegia . Photosynthetica, 24:53-55

Venter, O., Brodeur, N.N., Nemiroff, L., Belland, B., Dolinsek, L.J., and Grant, J.W.A. (2006). Threats to endangered species in Canada. Bio-Science, 56:903-10

Wilcove, D., Rothstein, D., Dubow, J., Phillips, A., and Losos, E. (2000). Leading threats to biodiversity: What's imperiling U.S. species. Pp. 239-54 in Precious heritage:The status of biodiversity in the United States. ed. B.A. Stein, L. S. Kutner, and J.S. Adams. New York: Oxford University Press.

Yadav, S.R (1996). Flytrap flowers of Western Ghats. Hornbill, $1: 1-7$ 